\title{
Description of research design of articles published in four Brazilian physical therapy journals
}

\author{
Bruno T. Saragiotto ${ }^{1}$, Lucíola C. M. Costa ${ }^{1}$, Ronaldo F. Oliveira ${ }^{1}$, \\ Alexandre D. Lopes ${ }^{1}$, Anne M. Moseley ${ }^{2}$, Leonardo O. P. Costa ${ }^{1,2}$
}

\begin{abstract}
Background: While the research design of articles published in medical journals and in some physical therapy journals has already been evaluated, this has not been investigated in Brazilian physical therapy journals. Objective: To describe the research design used in all articles published in Brazilian scientific journals that are freely available, have high Qualis rankings, and are relevant to physical therapy over a 7-year period. Method: We extracted the bibliometric data, research design, research type (human or animal), and clinical area for all articles published. The articles were grouped into their level of evidence, and descriptive analyses were performed. We calculated the frequency, proportions of articles, and 95\% confidence interval of these proportions with each research design in each journal. We cross-tabulated the clinical areas with research designs (expressed as number and percentages). Results: A total of 1,458 articles from four Brazilian journals were found: Revista Brasileira de Fisioterapia, Revista Fisioterapia em Movimento, Revista Fisioterapia e Pesquisa, and Revista Acta Fisiátrica. The majority of articles were classified as level II of evidence (60\%), followed by level III (29\%) and level I (10\%). The most prevalent research designs were cross-sectional studies $(38 \%)$, single-case or case-series studies, and narrative reviews. Most articles reported human research and were in the musculoskeletal, neurologic, and cardiothoracic areas. Conclusions: Most of the research published in Brazilian physical therapy journals used levels II and III of evidence. Increasing the publication rate of systematic reviews and randomized controlled trials would provide more high-quality evidence to guide evidence-based physical therapy practice.
\end{abstract}

Keywords: evidence-based practice; physical therapy; rehabilitation; scientific journals; research design.

\section{HOW TO CITE THIS ARTICLE}

Saragiotto BT, Costa LCM, Oliveira RF, Lopes AD, Moseley AM, Costa LOP. Description of research design of articles published in four Brazilian physical therapy journals. Braz J Phys Ther. 2014 Jan-Feb; 18(1):56-62. http://dx.doi.org/10.1590/ S1413-35552012005000136

\section{Introduction}

Evidence-based physical therapy is defined as the integration of high-quality clinical research, practice knowledge, and patient preferences ${ }^{1}$. One important step in accessing high-quality clinical research is the identification of the research design used and knowing where the research design is ranked in the hierarchy (or levels) of evidence ${ }^{2}$. In the hierarchy of research designs to answer questions about the effects of intervention, the highest levels of evidence are systematic reviews of randomized controlled trials $^{2,3}$. The hierarchy of research designs to answer questions about other aspects of healthcare (e.g. making a diagnosis or predicting prognosis) differs from questions about the effects of intervention. For example, systematic reviews of inception cohort studies followed by individual inception cohort studies are the highest levels of evidence for questions about prognosis, while diagnostic tests are best evaluated by systematic reviews of cross-sectional studies (which compare the clinical test to a reference standard) than by individual studies ${ }^{2}$.

The level of evidence of articles published in some journals appears to have increased over recent decades ${ }^{3-10}$. For example, the evidence index (an indicator of the study design from 0 to 6 , with higher values allocated to higher study designs) increased significantly between 1985 and 2010 in the Journal of Physiotherapy, Journal of Science and Medicine in Sport, and Physical Therapy ${ }^{9,10}$. With the exception of Torloni and Riera ${ }^{7}$, who evaluated Brazilian medical journals, these surveys focused on journals published in North America, Europe, and Australia.

\footnotetext{
${ }^{1}$ Master's and Doctoral Programs in Physical Therapy, Universidade Cidade de São Paulo (UNICID), São Paulo, SP, Brazil 
To our knowledge, the level of evidence of articles published in Brazilian physical therapy journals has not been evaluated.

Understanding the level of evidence in Brazilian physical therapy journals may provide a broader view about both the current state of research and the change and the trends in research output over time in Brazil. In addition, it would allow us to determine changes in the proportion of study designs over the last years. Therefore, the aim of this study was to describe the research design used in articles published in Brazilian scientific journals that are relevant to physical therapy or physical medicine and rehabilitation. Journals that are freely available online and have high Qualis rankings were evaluated. A longitudinal analysis was undertaken over the most recent 7-year period (2005 to 2011, inclusive).

\section{- Method}

This is a bibliometric study that classified the research design used in each article published in Brazilian scientific journals relevant to physical therapy and/or physical medicine and rehabilitation for the years 2005 to 2011, inclusive. The eligibility criteria for journal inclusion were (1) availability in an open access format over the internet and (2) high ranking by the Qualis system area 21 (which is related to physical therapy and physical medicine and rehabilitation). Qualis is a national ranking of scientific journals developed by the Coordination for Enhancement of Higher Education Personnel (Coordenação de Aperfeiçoamento de Pessoal de Nível Superior - CAPES) to rate the quality of research output of graduate programs (i.e. master's degree and doctoral programs) in Brazil. The Qualis system assesses the quality of scientific journals by all research areas annually. The journals are classified into eight quality strata, A1 being the highest, followed by A2, B1, B2, B3, B4, B5, and finally C.

The choice of the study period (i.e. five years) was determined by the availability of open access journals over this period of time. Only open access journals were included as these may be the main journals used by clinicians to support evidence-based practice ${ }^{11}$. If an occasional article was not publicly available, the journal editor was contacted to obtain a copy in portable document format (i.e. pdf). We selected the four highest ranked journals relevant to physical therapy to be included in this study.

All articles were downloaded from the journal websites on 1 June 2012. Bibliometric data (authors, title, journal, year, volume, issue, and page numbers) were collected and the research design, type of participants, and clinical area were classified for all articles in the included journals. The source of the information used to classify each article was also recorded (i.e. title, abstract or text). All data extraction and classification was performed by two independent reviewers and, in case of disagreement, consensus was obtained through discussion and, if necessary, through arbitration by a third reviewer.

Research designs were classified using an adapted version of the categories and levels of evidence used in two previous studies ${ }^{3,7}$ (see Table 1). If the article reported random allocation of participants to two or more interventions, the study was classified as a randomized controlled trial (the precise method of randomization did not have to be explained). If the

Table 1. Categories used to classify the research design of articles published in the included journals $\mathrm{s}^{3,7}$.

Level I

Clinical practice guidelines

Systematic reviews

Randomized controlled trials

Quasi-randomized controlled trials

Level II

Diagnostic accuracy studies

Cohort studies

Cross-sectional studies

Non-randomized controlled trials

Case-control studies

Single-case or case-series studies

Level III

Cadaveric or animal experimental studies

Narrative reviews

Development, translation, cross-cultural adaptation, and measurement properties of any measurement tool

Technical notes describing surgical procedures or anatomical findings

Professional quiz

Editorials

Letters to the editor

Clinical comments

Reflections of attitudes in clinical practice

Expert opinions

Other 
article reported that participants were allocated to groups using a pseudo-random process (e.g. by date of birth, hospital record number or alternation) the study was classified as a quasi-randomized controlled trial. If no information was provided about how participants were allocated to groups, the article was classified as a non-randomized controlled trial. For review articles, we classified articles which clearly reported the methods of the review as a systematic review. All other reviews were classified as a narrative review. The type of participants investigated in the articles was classified as human or animal/cadaveric.

The clinical area of each article was classified using the subdiscipline codes used in the Physiotherapy Evidence Database (PEDro) ${ }^{12}$. The codes were: 1 ) cardiothoracic; 2) continence and women's health; 3) ergonomics and occupational health; 4) gerontology; 5) musculoskeletal; 6) neurology; 7) oncology; 8) orthopedics; 9) pediatrics; 10) sports; and 11) other. The articles were grouped and ranked according to their level of evidence. The level of evidence was adapted by previous studies ${ }^{3,7}$ divided into three levels (see Table 1).

\section{Statistical analysis}

Descriptive analyses were performed. The total number (and percentage) of articles in each journal and each year were calculated. The total number (and percentage) of articles reporting human and animal/ cadaveric research were calculated. The frequency, proportions (and 95\% confidence interval of these proportions) of articles with each research design in each journal were calculated. Finally we crosstabulated the clinical areas with research designs (expressed as number and percentages).

\section{Results}

The four journals that met the inclusion criteria were: 1) Revista Brasileira de Fisioterapia (www. rbf-bjpt.org.br; Qualis ranking A2), 2) Revista Fisioterapia e Pesquisa (www.rfp-ptr.com.br; Qualis ranking B2), 3) Revista Fisioterapia em Movimento (www.pucpr.br/revfisio; Qualis ranking B1), and 4) Revista Acta Fisiátrica (www.actafisiatrica.org. br; Qualis ranking B2). The Revista Brasileira de Fisioterapia has published six issues per year since its first issue in 1996. The Revista Fisioterapia e Pesquisa has published three issues per year since 1994. The Revista Fisioterapia em Movimento has published three issues per year since its first issue in 1989. The Revista Acta Fisiátrica has published three issues per year since 1994.
A total of 1,458 articles were published between 2005 and 2011, inclusive. The Revista Brasileira de Fisioterapia contained the highest number of articles ( $\mathrm{n}=519,36 \%)$, followed by the Revista Fisioterapia em Movimento ( $\mathrm{n}=413,28 \%)$, Revista Fisioterapia e Pesquisa (n=325, 22\%), and Revista Acta Fisiátrica $(\mathrm{n}=201,14 \%)$. However, the articles published in Revista Acta Fisiátrica are not complete because the last three issues published in 2011 were unavailable when the articles were downloaded on 1 June 2012.

The highest proportion of articles was published in 2008 and then the average number of articles remained relatively constant. The number of articles published each year was: 123 articles (8\%) in 2005, $140(9 \%)$ in 2006, $221(15 \%)$ in 2007, $255(17 \%)$ in 2008, $242(16 \%)$ in 2009, $244(17 \%)$ in 2010, and 233 in $2011(16 \%)$. The data used to classify the research design were reported in the title or abstract in 1,145 articles (78\%), but the full-text had to be consulted for the remaining articles $(313,21 \%)$. The majority of articles $(1,286,88 \%)$ reported human research. Animal/cadaveric research was reported in 79 articles (5\%), and the remaining 93 articles (6\%) were editorials, comments, reflections, letters to the editor, etc., which could not be classified as human or animal/cadaveric.

The majority of articles were classified as level II (60\%) and level III (29\%) evidence (see Table 2). The most common study designs were crosssectional studies (38\%), single-case or case-series studies (13\%), and narrative reviews (9\%). The Revista Fisioterapia em Movimento had the highest proportion of level I evidence (15\%) followed by Revista Brasileira de Fisioterapia (9\%) and Revista Acta Fisiátrica (6\%). These proportions are not significantly different as the $95 \%$ confidence intervals for these proportions overlap.

The clinical areas with the highest proportion of level I evidence were orthopedics (18\%) and continence and women's health (17\%), and the clinical areas with the lowest proportion of level I evidence were sports (4\%) and pediatrics (2\%). The most prevalent clinical areas (regardless of the level of evidence) were musculoskeletal (27\%), neurology $(18 \%)$, and cardiothoracics (13\%), which equates to more than half of all articles published. On the other hand, oncology was the least studied clinical area, contributing less than $1 \%$ of the total articles. Table 3 presents the research design and level of evidence classified by the clinical area. 
Table 2. Number, percentage, and 95\% confidence intervals of different study designs published in each of the four Brazilian physical therapy journals.

\begin{tabular}{|c|c|c|c|c|c|}
\hline $\begin{array}{l}\text { Level of evidence and } \\
\text { research design }\end{array}$ & $\begin{array}{l}\text { Revista Brasileira } \\
\text { de Fisioterapia }\end{array}$ & $\begin{array}{c}\text { Fisioterapia em } \\
\text { Movimento }\end{array}$ & $\begin{array}{l}\text { Fisioterapia e } \\
\text { Pesquisa }\end{array}$ & Acta Fisiátrica & Total $(\%)$ \\
\hline Level I evidence & $\begin{array}{c}45 \\
8.7(6.5 \text { to } 11.4)\end{array}$ & $\begin{array}{c}62 \\
15(11.9 \text { to } 18.8)\end{array}$ & $\begin{array}{c}33 \\
10.1(7.3 \text { to } 13.9)\end{array}$ & $\begin{array}{c}12 \\
6(3.4 \text { to } 10.1)\end{array}$ & $152(10.5)$ \\
\hline Clinical practice guidelines & 0 & 0 & 0 & 0 & 0 \\
\hline Systematic reviews & $\begin{array}{c}8 \\
1.5(0.8 \text { to } 3.0)\end{array}$ & $\begin{array}{c}35 \\
8.5(6.2 \text { to } 11.6)\end{array}$ & $\begin{array}{c}13 \\
4.0(2.4 \text { to } 6.7)\end{array}$ & $\begin{array}{c}6 \\
3.0(1.4 \text { to } 6.4)\end{array}$ & $62(4.3)$ \\
\hline Randomized controlled trials & $\begin{array}{c}34 \\
6.6(4.7 \text { to } 9.0)\end{array}$ & $\begin{array}{c}27 \\
6.5(4.5 \text { to } 9.3)\end{array}$ & $\begin{array}{c}19 \\
5.8(3.8 \text { to } 9.0)\end{array}$ & $\begin{array}{c}6 \\
3.0(1.4 \text { to } 6.4)\end{array}$ & $86(5.9)$ \\
\hline $\begin{array}{l}\text { Quasi-randomized } \\
\text { controlled trials }\end{array}$ & $\begin{array}{c}3 \\
0.6(0.2 \text { to } 1.7)\end{array}$ & - & $\begin{array}{c}1 \\
0.3(0.1 \text { to } 1.7)\end{array}$ & - & $4(0.3)$ \\
\hline Level II evidence & $\begin{array}{c}311 \\
60.0(55.6 \text { to } 64.0)\end{array}$ & $\begin{array}{c}243 \\
58.8(54.0 \text { to } 63.5)\end{array}$ & $\begin{array}{c}211 \\
64.9(59.6 \text { to } 69.9)\end{array}$ & $\begin{array}{c}116 \\
57.7(50.8 \text { to } 64.3)\end{array}$ & $881(60.4)$ \\
\hline Diagnostic accuracy studies & 0 & 0 & 0 & 0 & 0 \\
\hline Cohort studies & $\begin{array}{c}24 \\
4.6(3.1 \text { to } 6.8)\end{array}$ & $\begin{array}{c}12 \\
2.9(1.6 \text { to } 5.0)\end{array}$ & $\begin{array}{c}12 \\
3.7(2.1 \text { to } 6.3)\end{array}$ & $\begin{array}{c}10 \\
5.0(2.7 \text { to } 8.9)\end{array}$ & $58(4.0)$ \\
\hline Cross-sectional studies & $\begin{array}{c}218 \\
42(37.8 \text { to } 46.3)\end{array}$ & $\begin{array}{c}156 \\
37.8(33.2 \text { to } 42.5)\end{array}$ & $\begin{array}{c}127 \\
39.1(34.0 \text { to } 44.5)\end{array}$ & $\begin{array}{c}59 \\
29.4(23.5 \text { to } 36.0)\end{array}$ & $560(38.4)$ \\
\hline $\begin{array}{l}\text { Non-randomized controlled } \\
\text { trials }\end{array}$ & $\begin{array}{c}20 \\
3.9(2.5 \text { to } 5.9)\end{array}$ & $\begin{array}{c}15 \\
3.6(2.2 \text { to } 5.9)\end{array}$ & $\begin{array}{c}18 \\
5.5(3.5 \text { to } 8.6)\end{array}$ & $\begin{array}{c}6 \\
3.0(1.4 \text { to } 6.4)\end{array}$ & $59(4.0)$ \\
\hline Case-control studies & $\begin{array}{c}4 \\
0.8(0.3 \text { to } 1.9)\end{array}$ & $\begin{array}{c}2 \\
0.5(0.1 \text { to } 1.8)\end{array}$ & $\begin{array}{c}3 \\
0.9(0.3 \text { to } 2.7)\end{array}$ & $\begin{array}{c}2 \\
1.0(0.3 \text { to } 3.6)\end{array}$ & $11(0.8)$ \\
\hline $\begin{array}{l}\text { Single-case or case-series } \\
\text { studies }\end{array}$ & $\begin{array}{c}45 \\
8.7(6.5 \text { to } 11.4)\end{array}$ & $\begin{array}{c}58 \\
14.0(11.0 \text { to } 17.7)\end{array}$ & $\begin{array}{c}51 \\
15.7(12.1 \text { to } 20.0)\end{array}$ & $\begin{array}{c}39 \\
19.4(14.5 \text { to } 25.4)\end{array}$ & $193(13.2)$ \\
\hline Level III evidence & $\begin{array}{c}162 \\
31.2(27.4 \text { to } 35.3)\end{array}$ & $\begin{array}{c}108 \\
26.2(22.1 \text { to } 30.6)\end{array}$ & $\begin{array}{c}81 \\
24.9(20.5 \text { to } 29.9)\end{array}$ & $\begin{array}{c}70 \\
34.8(28.5 \text { to } 41.6)\end{array}$ & $421(29.1)$ \\
\hline $\begin{array}{l}\text { Cadaveric or animal } \\
\text { experimental studies }\end{array}$ & $\begin{array}{c}42 \\
8.1(6.0 \text { to } 10.8)\end{array}$ & $\begin{array}{c}13 \\
3.2(1.8 \text { to } 5.3)\end{array}$ & $\begin{array}{c}22 \\
6.8(4.5 \text { to } 10.0)\end{array}$ & $\begin{array}{c}2 \\
1.0(0.3 \text { to } 3.6)\end{array}$ & $79(5.4)$ \\
\hline Narrative reviews & $\begin{array}{c}24 \\
4.6(3.1 \text { to } 6.8)\end{array}$ & $\begin{array}{c}54 \\
13.1(10.2 \text { to } 16.7)\end{array}$ & $\begin{array}{c}18 \\
5.5(3.5 \text { to } 8.6)\end{array}$ & $\begin{array}{c}43 \\
21.4(16.3 \text { to } 27.6)\end{array}$ & $139(9.5)$ \\
\hline $\begin{array}{l}\text { Development, translation, } \\
\text { cross-cultural adaptation, } \\
\text { and measurement properties } \\
\text { of any measurement tool }\end{array}$ & $\begin{array}{c}47 \\
9.0(6.9 \text { to } 11.8)\end{array}$ & $\begin{array}{c}8 \\
1.9(1.0 \text { to } 3.8)\end{array}$ & $\begin{array}{c}13 \\
4.0(2.4 \text { to } 6.7)\end{array}$ & $\begin{array}{c}9 \\
4.5(2.4 \text { to } 8.3)\end{array}$ & $77(5.3)$ \\
\hline $\begin{array}{l}\text { Technical notes describing } \\
\text { surgical procedures or } \\
\text { anatomical findings }\end{array}$ & 0 & 0 & 0 & 0 & 0 \\
\hline Professional quiz & 0 & 0 & 0 & 0 & 0 \\
\hline Editorials & $\begin{array}{c}38 \\
7.3(5.4 \text { to } 9.9)\end{array}$ & $\begin{array}{c}22 \\
5.3(3.5 \text { to } 7.9)\end{array}$ & $\begin{array}{c}22 \\
6.8(4.5 \text { to } 10.0)\end{array}$ & $\begin{array}{c}7 \\
3.5(1.7 \text { to } 7.0)\end{array}$ & $89(6.1)$ \\
\hline Letter to the editor & $\begin{array}{c}9 \\
1.7(0.9 \text { to } 3.3)\end{array}$ & 0 & 0 & $\begin{array}{c}3 \\
1.5(0.5 \text { to } 4.3)\end{array}$ & $12(0.8)$ \\
\hline Clinical comments & 0 & $\begin{array}{c}2 \\
0.5(0.1 \text { to } 1.8)\end{array}$ & $\begin{array}{c}2 \\
0.6(0.2 \text { to } 2.2)\end{array}$ & 0 & $4(0.3)$ \\
\hline $\begin{array}{l}\text { Reflections of attitudes in } \\
\text { clinical practice }\end{array}$ & $\begin{array}{c}2 \\
0.4(0.1 \text { to } 1.4)\end{array}$ & $\begin{array}{c}4 \\
1.0(0.4 \text { to } 2.5)\end{array}$ & $\begin{array}{c}2 \\
0.6(0.2 \text { to } 2.2)\end{array}$ & $\begin{array}{c}9 \\
4.5(2.4 \text { to } 8.3)\end{array}$ & $17(1.2)$ \\
\hline Expert opinions & 0 & $\begin{array}{c}3 \\
0.7(0.2 \text { to } 2.1)\end{array}$ & 0 & 0 & $3(0.2)$ \\
\hline Other & $\begin{array}{c}1 \\
0.2(0.03 \text { to } 1.1)\end{array}$ & $\begin{array}{c}2 \\
0.5(0.1 \text { to } 1.7)\end{array}$ & $\begin{array}{c}2 \\
0.6(0.2 \text { to } 2.2)\end{array}$ & 0 & $5(0.3)$ \\
\hline
\end{tabular}




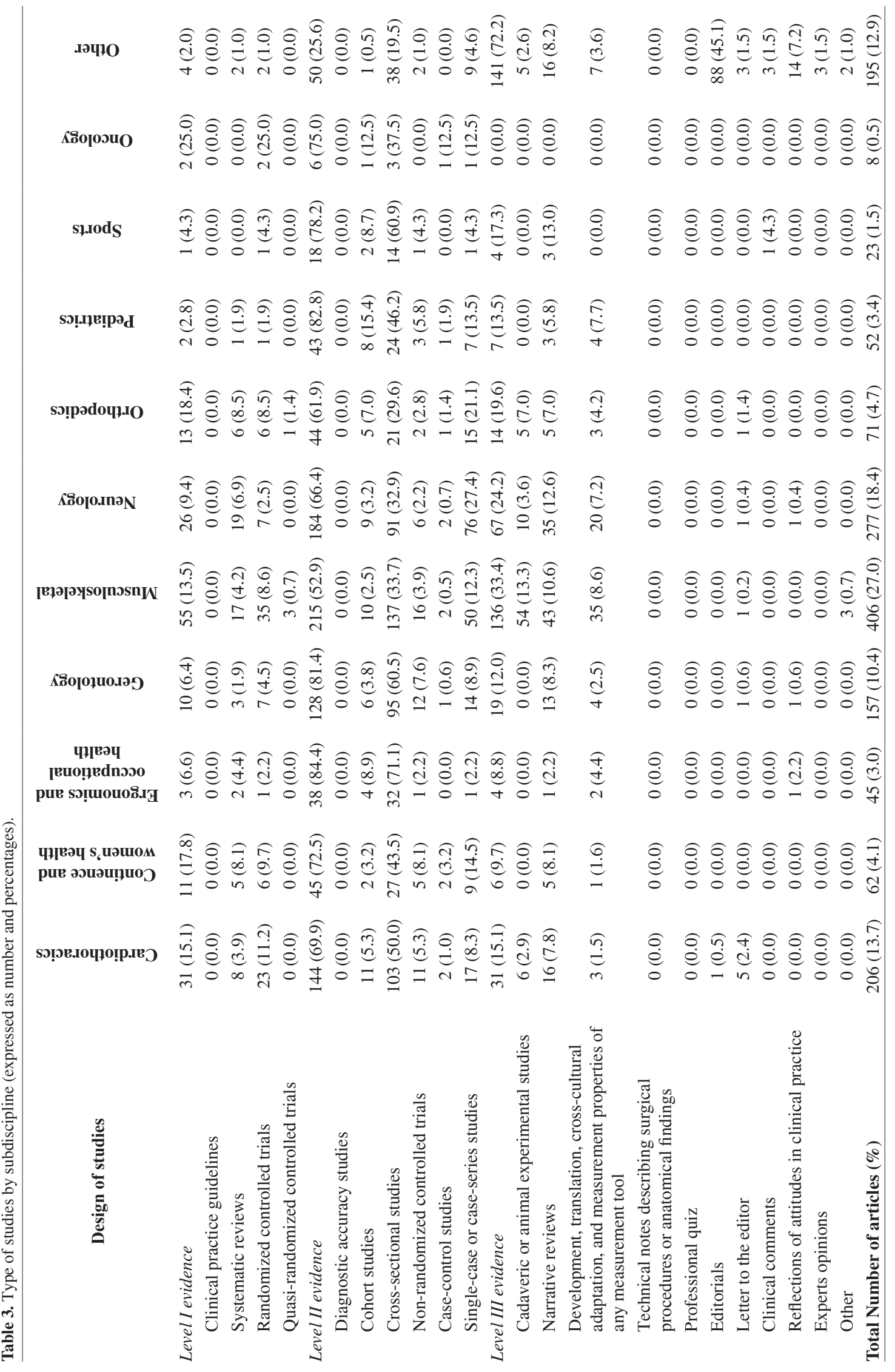




\section{- Discussion}

We analyzed 1,458 articles from the four different Brazilian physical therapy journals (Revista Brasileira de Fisioterapia, Revista Fisioterapia em Movimento, Revista Fisioterapia e Pesquisa, Revista Acta Fisiátrica) with high Qualis rankings published from 2005 to 2011 . The majority of articles were classified as level II evidence (60\%), followed by level III (29\%) and level I (10\%), and this pattern was consistent across all four journals. The most common study designs were cross-sectional studies, single-case and case-series studies, and narrative reviews, and the most prevalent clinical areas were musculoskeletal, neurology, and cardiothoracics.

Cross-sectional studies were the most prevalent design for the Brazilian physical therapy journals evaluated and correspond to approximately $40 \%$ of all articles published. This is consistent with previous surveys which also report that cross-sectional studies are the most common study design in Brazilian medical journals ${ }^{7}$ and other international physical therapy journals ${ }^{6}$. One explanation for this high prevalence of cross-sectional studies (plus some other designs classified as level II and III evidence) is that the methods are simple, require less time, and are cheaper compared to randomized controlled trials or well-conducted prospective cohort studies, making them relatively easier to conduct.

The proportion of articles classified as level I evidence was about $10 \%$ of all articles evaluated. This may be higher than the level I evidence published in Brazilian medical journals $(4 \%)^{7}$ but it is lower than the surveys of international physical therapy journals (about 15\%) ) $^{3,6,13}$. The publication of level I evidence (i.e. systematic reviews, randomized controlled trials) is extremely important because this high-quality research is considered the best evidence possible to evaluate the effects of interventions, predict outcomes, and make a clinical diagnosis ${ }^{1}$. This study screened the four highest ranked Brazilian physical therapy journals and the data from these journals are likely to be representative of the current scenario of physical therapy research in Brazil with few articles classified as high-quality research. However, the journals included in our survey are currently ranked as A2 and B1 using the Qualis ranking system. Perhaps Brazilian physical therapy researchers have been publishing their clinical trials and reviews in higher impact journals (e.g. A1 Qualis ranking) or in journals published outside Brazil, which may explain the small proportion of randomized controlled trials in Brazilian physical therapy journals.

Strategies which may increase the proportion of level I evidence in Brazilian physical therapy journals could include inviting contributions, offering an expedited review process in order to attract more systematic reviews and randomized controlled trials, and publishing the contents of each issue in the order of levels of evidence (i.e., systematic reviews then clinical trials then observational studies).

The main clinical areas of articles published in the Brazilian physical therapy journals we surveyed were musculoskeletal, neurologic, and cardiothoracic. This is not surprising as these three areas of physical therapy also have the greatest number of articles in the PEDro database. ${ }^{14}$ The number of publications in Brazilian physical therapy journals increased between 2005 and 2008, and after that the number of publications has remained relatively constant, mirroring the physical therapy scientific output in Brazil. While we did not evaluate the association between time and the proportion of study designs published, several studies suggest that the level of evidence has been increasing over recent decades ${ }^{3,9,10}$. For example, Wiles et al. ${ }^{10}$ evaluated all research published in seven Australian nursing and allied health journals over the lifetime of each journal. They found that all journals investigated followed a similar trajectory in a move towards a higher level of evidence, a greater collaboration between authors, and greater quantification in results reporting over time. Applying a similar analysis to Brazilian physical therapy journals could be the focus of future research.

We were able to identify the study design by examining the title and abstract in $78.5 \%$ of the articles we evaluated. This is consistent with a recent study investigating the quality of reporting of physical therapy systematic reviews in Brazilian journals which concluded that reporting was generally poor ${ }^{15}$. Including the study design in the title and abstract allows clinicians to quickly identify appropriate articles to answer their clinical questions and is one of the recommendations made by the EQUATOR (Enhancing the QUAlity and Transparency Of health Research) Network to increase transparent reporting in health research ${ }^{16}$. Incorporating international standards like trial registration ${ }^{17}$ and the CONSORT $^{18}$ and PRISMA ${ }^{19}$ statements into the editorial guidelines of journals may make it easier for physical therapists to access relevant high-quality research.

One limitation of our study is that we evaluated four Brazilian physical therapy journals and we based our analyses on the published articles only. As we selected the highest ranking physical therapy journals, our results may not be generalizable to other journals and may overestimate the quantity of level I evidence published across all Brazilian physical therapy journals. We decided to extract data 
solely from the published articles as this is the main source of information for the end-users of research (researchers, educators, students, and clinicians), but acknowledge that other data (including study protocols and electronic appendices) may also be available.

\section{Conclusion}

The four highest ranked Brazilian physical therapy journals were Revista Brasileira de Fisioterapia, Revista Fisioterapia em Movimento, Revista Fisioterapia e Pesquisa, and Revista Acta Fisiátrica. All journals published a high proportion of level II and III evidence, with just $10 \%$ of articles being classified as level I. If the aim of Brazilian physical therapy journals is to disseminate high-quality research to guide the practice and teaching of physical therapy, more level 1 evidence needs to be included.

\section{References}

1. Herbert RD, Jamtvedt G, Hagen BK, Mead J. Practical Evidence-Based Physiotherapy. 2nd ed. London: Churchill Livingstone; 2011. 186 p.

2. Jeremy H, Iain C, Paul G, Trish G, Carl H, Alessandro L, et al. The 2011 Oxford CEBM Levels of Evidence (Introductory Document) [Internet]. 2011. Available from: http://www.cebm.net/index.aspx?o=5513.

3. Kocak FU, Unver B, Karatosun V. Level of evidence in four selected rehabilitation journals. Arch Phys Med Rehabil. 2011;92(2):299-303. PMid:21272728. http:// dx.doi.org/10.1016/j.apmr.2010.07.233

4. Bleakley C, MacAuley D. The quality of research in sports journals. Br J Sports Med. 2002;36(2):124-5. http://dx.doi. org/10.1136/bjsm.36.2.124

5. Kiter E, Karatosun V, Gunal I. Do orthopaedic journals provide high-quality evidence for clinical practice? Arch Orthop Trauma Surg. 2003;123(2-3):82-5. PMid:12721685.

6. Paci M, Cigna C, Baccini M, Rinaldi LA. Types of article published in physiotherapy journals: a quantitative analysis. Physiother Res Int. 2009;14(4):203-12. PMid:19746407. http://dx.doi.org/10.1002/pri.447

7. Torloni MR, Riera R. Design and level of evidence of studies published in two Brazilian medical journals recently indexed in the ISI Web of Science database. Sao Paulo Med J. 2010;128(4):202-5. http://dx.doi. org/10.1590/S1516-31802010000400005

8. Ubriani R, Smith N, Katz KA. Reporting of study design in titles and abstracts of articles published in clinically oriented dermatology journals. Br J Dermatol. 2007;156(3):557-9. PMid:17300248. http://dx.doi. org/10.1111/j.1365-2133.2006.07705.x

9. Wiles L, Matricciani L, Williams M, Olds T. Sixty-five years of Physical Therapy: bibliometric analysis of research publications from 1945 through 2010. Phys
Ther. 2011;92(4):493-506. PMid:22194279. http://dx.doi. org/10.2522/ptj.20110013

10. Wiles L, Olds T, Williams M. Twenty-five years of Australian nursing and allied health professional journals: bibliometric analysis from 1985 through 2010. Scientometrics. 2012;94(1):359-78. http://dx.doi. org/10.1007/s11192-012-0704-y

11. Wentz R. Visibility of research: FUTON bias. Lancet. 2002;360(9341):1256. PMid:12401287. http://dx.doi. org/10.1016/S0140-6736(02)11264-5

12. Centre for Evidence-Based Physiotherapy PEDro. Códigos [Internet]. 2012. Available from: http://www. pedro.org.au/english/downloads/codes/.

13. Paci M, Briganti G, Lombardi B. Levels of evidence of articles published in Physical and Rehabilitation Medicine journals. J Rehabil Med. 2011;43(3):264-7. PMid:21394416. http://dx.doi. org/10.2340/16501977-0665

14. Sherrington C, Moseley AM, Herbert RD, Elkins MR, Maher CG. Ten years of evidence to guide physiotherapy interventions: Physiotherapy Evidence Database (PEDro). Br J Sports Med. 2009;44(12):836-7. PMid:19846426. http://dx.doi.org/10.1136/bjsm.2009.066357

15. Padula RS, Pires RS, Alouche SR, Chiavegato LD, Lopes $\mathrm{AD}$, Costa LO. Analysis of reporting of systematic reviews in physical therapy published in Portuguese. Rev Bras Fisioter. 2012;16(4):381-8. PMid:22858736. http://dx.doi. org/10.1590/S1413-35552012005000040

16. Costa LO, Maher CG, Lopes AD, De Noronha MA, Costa LC. Transparent reporting of studies relevant to physical therapy practice. Rev Bras Fisioter. 2011;15(4):26771. PMid:21975681. http://dx.doi.org/10.1590/ S1413-35552011005000009

17. Costa LO, Lin CW, Grossi DB, Mancini MC, Swisher $\mathrm{AK}$, Cook $\mathrm{C}$, et al. Clinical trial registration in physical therapy journals: recommendations from the International Society of Physiotherapy Journal Editors. Rev Bras Fisioter. 2013;16(6):v-ix. http://dx.doi.org/10.1590/ S1413-35552012000600001

18. Schulz KF, Altman DG, Moher D. CONSORT 2010 statement: updated guidelines for reporting parallel group randomised trials. Int J Surg. 2011;9(8):6727. PMid:22019563. http://dx.doi.org/10.1016/j. ijsu.2011.09.004

19. Liberati A, Altman DG, Tetzlaff J, Mulrow C, Gotzsche PC, Ioannidis JP, et al. The PRISMA statement for reporting systematic reviews and meta-analyses of studies that evaluate healthcare interventions: explanation and elaboration. BMJ. 2009;339:b2700. PMid:19622552 PMCid:PMC2714672. http://dx.doi.org/10.1136/bmj. b2700

\section{Correspondence}

\section{Bruno Tirotti Saragiotto}

Rua Diogo Ortiz, 273, Lapa

CEP 05077-100, São Paulo, SP, Brasil

e-mail: bruno.saragiotto@gmail.com 